\title{
Profil Penguasaan Konsep Sistem Periodik Unsur pada Siswa Kelas X MIPA SMA Negeri 1 Palangka Raya Tahun Ajaran 2018/2019
}

\author{
Hasa Oktavia, I Made Sadiana, Nopriawan Berkat Asi \\ Program Studi Pendidikan Kimia, FKIP, Universitas Palangka Raya, Indonesia \\ E-mail: shaokta96@gmail.com
}

\begin{abstract}
ABSTRAK
Kimia memiliki beberapa jenis konsep dari segi dimensinya, salah satunya adalah keabstrakan. Sistem periodik unsur merupakan salah satu materi dalam kimia yang bersifat abstrak. Tujuan penelitian ini adalah untuk mendeskripsikan penguasaan konsep siswa kelas X MIPA 7 SMA Negeri 1 Palangka Raya.

Subjek penelitian ini adalah 28 siswa kelas X MIPA 7 SMA Negeri 1 Palangka Raya tahun ajaran 2018/2019 yang sudah menerima pembelajaran sistem periodik unsur. Data penelitian ini berupa dokumen RPP yang didapat dari guru yang bersangkutan, data penguasaan konsep yang didapat melalui tes uraian sistem periodik unsur berjumlah 11 butir soal dari 3 indikator dan data hasil wawancara siswa. Data-data yang diperoleh kemudian dianalisis secara deskriptif.

Hasil penelitian menunjukkan bahwa profil penguasaan konsep siswa pada topik sistem periodik unsur yaitu sebesar $61,7 \%$ dan berada pada kategori sedang. Penguasaan konsep siswa terbagi kedalam 2 kategori yaitu tinggi dan sedang. Sebanyak 5 siswa berada pada kategori tinggi, dan sebanyak 23 siswa berada pada kategori sedang. Siswa mampu menjelaskan perkembangan sistem periodik unsur menurut Triade Döbereiner, Oktaf Newlands, Mendeleev, dan Moseley dengan penguasaan konsep sebesar $37,5 \%$ dan berada pada kategori rendah. Siswa mampu menentukan letak suatu unsur di dalam tabel periodik berdasarkan konfigurasi elektron dengan penguasaan konsep sebesar $100 \%$ dan berada pada kategori tinggi. Siswa mampu menentukan sifat periodik suatu unsur berdasarkan sifat keperiodikan unsur seperiode dengan penguasaan konsep sebesar 56,8\% dan berada pada kategori sedang.
\end{abstract}

Kata Kunci: penguasaan, konsep, sistem periodik unsur

\section{Pendahuluan}

Ilmu kimia merupakan salah satu pelajaran tersulit bagi kebanyakan siswa menengah, hingga jarang diminati. Hal tersebut disebabkan: (1) Dalam pelajaran kimia terdapat istilah-istilah yang hanya dihafal siswa tetapi tidak dipahami dengan benar; (2) Kebanyakan konsep-konsep atau materi kimia bersifat abstrak seperti atom, molekul atau ion sehingga siswa sulit membayangkan keberadaan materi tersebut tanpa mengalaminya secara langsung; (3) Kesulitan siswa dalam 
memahami perhitungan matematis materi kimia (Arifin, 1995). Salah satu pokok bahasan yang dipelajari siswa SMA adalah sistem periodik unsur, pada kurikulum 2013 sub pokok bahasan ini diajarkan di kelas X SMA semester ganjil. Jika siswa tidak memahami dengan benar konsep pada materi tersebut maka siswa akan kesulitan dalam belajar sistem periodik unsur, sehingga konsep yang dimiliki siswa terhadap materi sistem periodik unsur ini kurang. Hal tersebut didukung oleh penelitian Sanjaya (2017) menggunakan model kooperatif tipe STAD (Student Team Achievement Division) berbantuan LKS-induktif rata-rata persentase penguasaan konsep siswa pada materi sifat-sifat keperiodikan unsur tersebut sebanyak 66,38\%. Kemudian hasil penelitian Rahmaningsih (2012), menggunakan Instrumen Diagnostik Twotier menunjukkan bahwa penguasaan sebagian besar siswa pada keperiodikan unsur tergolong sangat rendah. Selain itu, ditemukan juga beberapa miskonsepsi. Kemudian hasil penelitian Mawarni (2017) mendeskripsikan penguasaan siswa melalui tes uraian diperoleh rata-rata skor siswa yaitu $18,14 \%$ dengan nilai rata-rata siswa yaitu $49,01 \%$. Rata-rata nilai siswa pada materi struktur atom dan sistem periodik unsur masih rendah karena berada dibawah nilai KKM yang ditetapkan oleh sekolah yaitu 80 , artinya siswa belum tuntas.

Penelitian di atas telah dilakukan dengan memberikan perlakuan kepada siswa, dimana dalam penelitian tersebut peneliti berupaya meningkatkan hasil belajar siswa dan mendeskripsikan penguasaan konsep siswa. Oleh karena itu, diperlukan adanya analisis terhadap kesalahan yang dilakukan siswa dalam menyelesaikan soal-soal sistem periodik unsur beserta penyebab kesalahannya sehingga kesalahan tersebut tidak terjadi secara berlanjut dan dapat ditentukan 
secara tepat bentuk remediasi untuk permasalahan ini. Sebagaimana penjelasan tersebut, peneliti hendak mengetahui sejauh mana penguasaan konsep siswa ditinjau dari proses pembelajaran di sekolah melalui pemberian tes tanpa diberikan suatu perlakuan terhadap subjek penelitian. Kesalahan siswa dalam menjawab soal nantinya dikaitkan dengan RPP guru, materi pembelajaran yang diajarkan di kelas, dan dikonfirmasikan dengan guru. Hasil belajar siswa akan menggambarkan apakah tujuan pembelajaran yang dilangsungkan tercapai atau belum tercapai.

Berdasarkan uraian diatas, maka dalam penelitian ini akan dikaji tentang "Profil Penguasaan Konsep Sistem Periodik Unsur pada Siswa Kelas X MIPA 7 SMA Negeri 1 Palangka Raya Tahun Ajaran 2018/2019”.

Penelitian ini bertujuan untuk mendeskripsikan profil penguasaan konsep sistem periodik unsur pada siswa kelas X MIPA 7 SMA Negeri 1 Palangka Raya Tahun Ajaran 2018/2019.

\section{Metodologi Penelitian}

Penelitian ini menggunakan metode deskriptif. Penelitian ini dilaksanakan di SMA Negeri 1 Palangka Raya yang beralamat di Jl. A.I.S Nasution No.02, Kecamatan Pahandut, Kota Palangka Raya. Adapun subjek penelitian ini adalah 28 siswa kelas X MIPA 7 SMA Negeri 1 Palangka Raya Tahun Ajaran 2018/2019 kota Palangka Raya, Kalimantan Tengah. Siswa tersebut telah menerima pembelajaran sistem periodik unsur. Pengambilan data dilaksanakan pada 12 Oktober 2018 dengan alokasi waktu yang diberikan untuk mengerjakan soal sebanyak 2 jam pelajaran. 
Data yang digunakan pada penelitian ini, antara lain meliputi dokumen RPP guru, data hasil tes siswa, dan data hasil wawancara. Data tersebut digunakan untuk memperoleh informasi penguasaan konsep siswa terhadap materi sistem periodik unsur, dan mengetahui penyebab kesalahan siswa dalam menjawab soal.

Teknis analisis data dalam penelitian ini berupa analisis RPP guru, analisis data penguasaan konsep siswa, dan hasil wawancara.

Analisis data RPP dilakukan dengan langkah-langkah berikut:

1. Peneliti menganalisis komponen kelengkapan isi RPP. Komponen yang dianalisis sebagai berikut.

Tabel 1. Komponen Kelengkapan RPP

\begin{tabular}{|c|c|c|c|}
\hline No & Aspek yang Diamati & Ada & $\begin{array}{c}\text { Tidak } \\
\text { Ada }\end{array}$ \\
\hline \multirow{7}{*}{1} & Identitas Sekolah & & \\
\hline & A. Satuan Pendidikan & & \\
\hline & B. Kelas & & \\
\hline & C. Semester & & \\
\hline & D. Mata Pelajaran & & \\
\hline & E. Materi Pokok & & \\
\hline & F. Alokasi Waktu & & \\
\hline \multirow{5}{*}{2} & Kompetensi Inti & & \\
\hline & A $\quad$ KI-1 & & \\
\hline & $\begin{array}{ll}\text { B } & \mathrm{KI}-2 \\
\end{array}$ & & \\
\hline & C $\quad \mathrm{KI}-3$ & & \\
\hline & $\begin{array}{ll}\mathrm{D} & \mathrm{KI}-4 \\
\end{array}$ & & \\
\hline 3 & Kompetensi Dasar & & \\
\hline 4 & Indikator & & \\
\hline 5 & Tujuan Pembelajaran & & \\
\hline 6 & Materi Pembelajaran & & \\
\hline 7 & Metode Pembelajaran & & \\
\hline 8 & Media Pembelajaran & & \\
\hline 9 & Sumber Belajar & & \\
\hline \multirow{5}{*}{10} & Rencana Kegiatan Pembelajaraan & & \\
\hline & Kegiatan pendahuluan/awal & & \\
\hline & 1) Mengkondisikan peserta didik & & \\
\hline & $\begin{array}{l}\text { 2) Mengkaitkan materi sebelumnya } \\
\text { dengan materi yang akan }\end{array}$ & & \\
\hline & 3) Menyampaikan tujuan & & \\
\hline
\end{tabular}




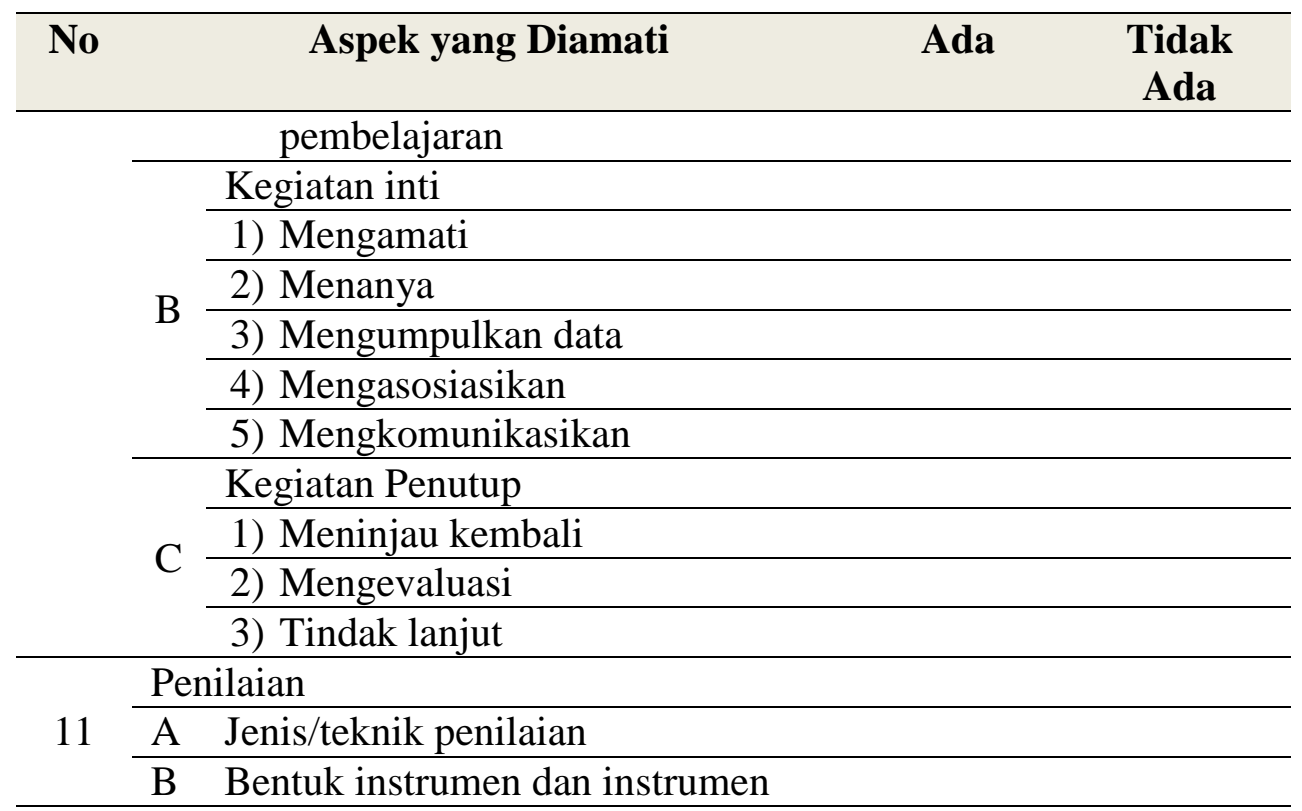

2. Peneliti menganalisis kesesuian isi RPP berkaitan dengan KI (kompetensi inti), KD (kompetensi dasar), indikator pencapaian kompetensi, tujuan pembelajaran, dan materi pembelajaran.

Analisis data penguasaan konsep dilakukan dengan langkah-langkah berikut:

1. Jawaban siswa skor sebagai data untuk mengetahui skor siswa sesuai dengan kriteria penskoran. Soal yang digunakan dalam penelitian ini berbentuk uraian yang berjumlah 11 butir soal. Hasil skor yang diperoleh digunakan untuk mendeskripsikan penguasaan konsep siswa tentang sistem periodik unsur.

2. Total perolehan skor seluruh siswa digunakan untuk menentukan penguasaan konsep siswa secara keseluruhan menggunakan rumus:

$$
\text { penguasaan konsep siswa }=\frac{\text { Jumlah skor jawaban yang diperoleh }}{\text { Jumlah skor total }} \times 100 \%
$$


3. Penguasaan konsep siswa dikategorisasi sesuai kriteria penguasaan konsep yang disarankan oleh Arikunto (2007).

Tabel 2. Rentang Persentase Tingkat Penguasaan Konsep

\begin{tabular}{cc}
\hline Nilai (\%) & Kategori \\
\hline $0 \%-45 \%$ & Rendah \\
\hline $46 \%-65 \%$ & Sedang \\
\hline $66 \%-85 \%$ & Tinggi \\
\hline $86 \%-100 \%$ & Sangat Tinggi \\
\hline
\end{tabular}

4. Penguasaan konsep siswa dideskripsikan berdasarkan jawaban siswa pada masing-masing kategori tingkat penguasaan konsep siswa.

5. Penguasaan konsep pada materi sistem periodik unsur merupakan rata-rata dari penguasaan konsep yang diukur dari pencapaian indikatornya, ditentukan dengan rumus:

$$
\text { penguasaan konsep }=\frac{\sum \text { pencapaian indikator }}{\sum \text { indikator }}
$$

Hasil wawancara siswa dianalisis dengan teknik triangulasi. Teknik triangulasi yaitu teknik pemeriksaan keabsahan data yang memanfaatkan sesuatu yang lain dalam membandingkan hasil wawancara terhadap objek penelitian (Moloeng, 2004). Hasil wawancara dianalisis dengan cara sebagai berikut:

1. Hasil wawancara siswa dikonfirmasi dengan hasil jawaban siswa.

2. Hasil wawancara siswa dikonfirmasi dengan dokumentasi RPP guru kimia yang mengajar.

3. Hasil wawancara siswa dikonfirmasi dengan hasil wawancara guru.

\section{Pembahasan}

Hasil jawaban siswa kemudian diolah sebagai data penguasaan konsep siswa. Butir soal pada tes uraian mewakili konsep-konsep pada materi sistem 
periodik unsur, dimana setiap butir soal memiliki kriteria penskoran. Total skor yang didapatkan siswa dikonversi dalam bentuk persentase dan kemudian diklasifikasikan. Persentase penguasaan konsep siswa pada materi sistem periodik unsur disajikan pada Tabel 3.

Tabel 3. Penguasaan Konsep Siswa pada Materi Sistem Periodik Unsur

\begin{tabular}{|c|c|c|c|c|}
\hline Indikator & Sub Indikator & $\begin{array}{c}\text { Buti } \\
\mathbf{r} \\
\text { Soal }\end{array}$ & $\begin{array}{l}\text { Penguasa } \\
\text { an } \\
\text { Konsep } \\
(\%)\end{array}$ & $\begin{array}{c}\text { Katego } \\
\text { ri }\end{array}$ \\
\hline \multirow{2}{*}{$\begin{array}{c}\text { Menjelaskan } \\
\text { perkembanga } \\
\text { n sistem } \\
\text { periodik } \\
\text { unsur }\end{array}$} & $\begin{array}{l}\text { Mendeskripsikan dasar penyusun } \\
\text { tabel sistem periodik unsur Triade } \\
\text { Döbereiner, Oktaf Newlands, dan } \\
\text { Mendeleev }\end{array}$ & 1 & 25 & $\begin{array}{c}\text { Renda } \\
\text { h }\end{array}$ \\
\hline & $\begin{array}{l}\text { Mendeskripsikan dasar penyusun } \\
\text { tabel sistem periodik Modern }\end{array}$ & 2 & 50 & Sedang \\
\hline \multirow{3}{*}{$\begin{array}{l}\text { Menentukan } \\
\text { letak suatu } \\
\text { unsur di } \\
\text { dalam tabel } \\
\text { periodik } \\
\text { berdasarkan } \\
\text { konfigurasi } \\
\text { elektron }\end{array}$} & $\begin{array}{l}\text { Menuliskan konfigurasi elektron } \\
\text { unsur golongan utama dan golongan } \\
\text { transisi }\end{array}$ & $3 . \mathrm{a}$ & 100 & Tinggi \\
\hline & $\begin{array}{l}\text { Menentukan golongan dan periode } \\
\text { suatu unsur berdasarkan konfigurasi } \\
\text { elektron }\end{array}$ & $3 . b$ & 100 & Tinggi \\
\hline & $\begin{array}{l}\text { Menentukan letak unsur pada tabel } \\
\text { periodik }\end{array}$ & 3.c & 100 & Tinggi \\
\hline \multirow{6}{*}{$\begin{array}{l}\text { Menentukan } \\
\text { sifat periodik } \\
\text { suatu unsur }\end{array}$} & $\begin{array}{l}\text { Mendeskripsikan sifat logam suatu } \\
\text { unsur }\end{array}$ & 4 & 53,6 & Sedang \\
\hline & $\begin{array}{l}\text { Mendeskripsikan titik didih dan titik } \\
\text { leleh suatu unsur }\end{array}$ & 5 & 58,9 & Sedang \\
\hline & $\begin{array}{l}\text { Menentukan jari-jari atom terkecil } \\
\text { hingga terbesar dari suatu unsur }\end{array}$ & $6 . \mathrm{a}$ & 57,1 & Sedang \\
\hline & $\begin{array}{l}\text { Menentukan energi ionisasi terkecil } \\
\text { hingga terbesar dari suatu unsur }\end{array}$ & 6.b & 58,9 & Sedang \\
\hline & $\begin{array}{l}\text { Menentukan afinitas elektron terkecil } \\
\text { hingga terbesar dari suatu unsur }\end{array}$ & 6.c & 57,1 & Sedang \\
\hline & $\begin{array}{l}\text { Menentukan keelektronegatifan } \\
\text { terkecil hingga terbesar dari suatu } \\
\text { unsur }\end{array}$ & 6.d & 55,4 & Sedang \\
\hline \multicolumn{3}{|c|}{ Rata-Rata Penguasaan Konsep } & 61,7 & an \\
\hline
\end{tabular}




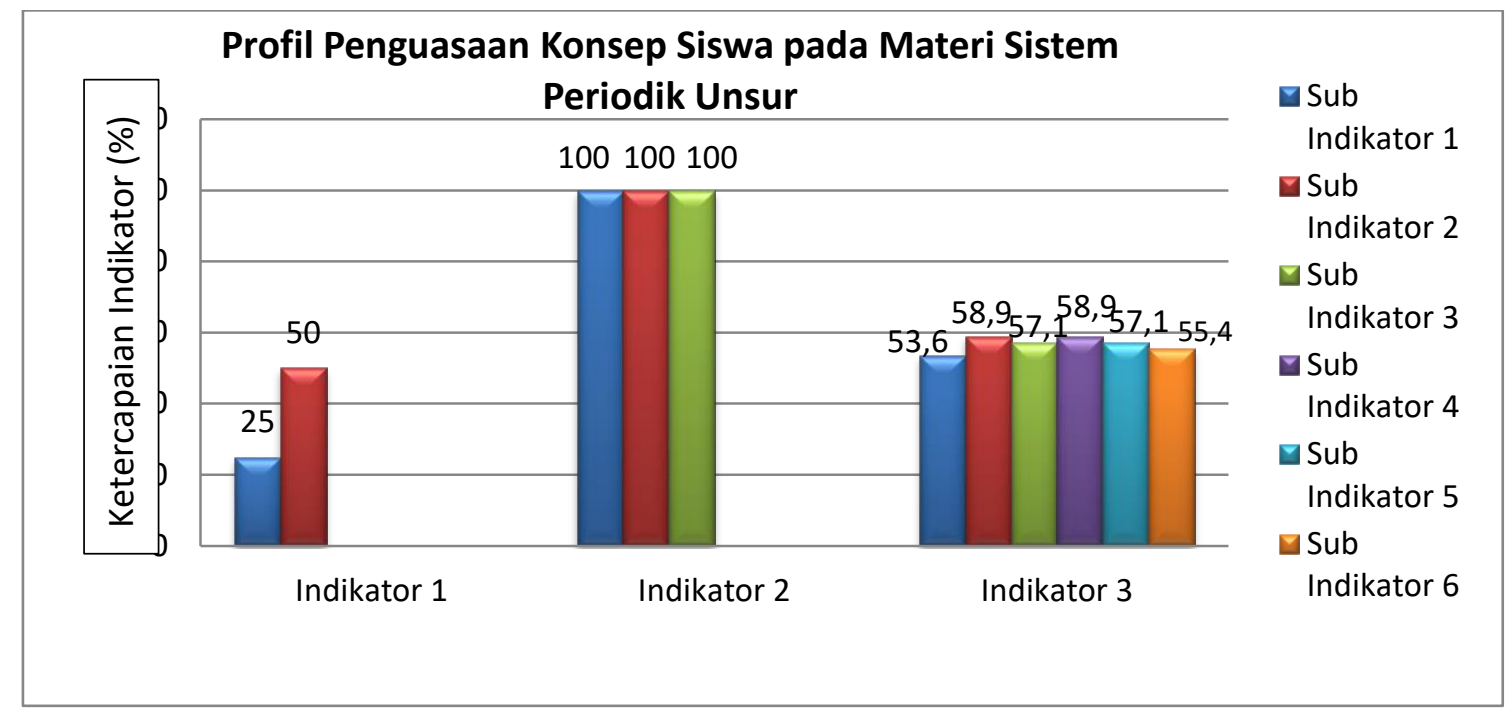

\section{Gambar 1. Grafik Data Ketercapaian Penguasaan Konsep Siswa dari Indikator 1 sampai Indikator 3}

Tabel 3 dan gambar 1 di atas merupakan hasil olahan data rata-rata perolehan skor siswa per sub indikator pada materi sistem periodik unsur. Grafik tersebut menunjukkan bahwa capaian penguasaan konsep siswa pada indikator 1 dengan rata-rata sebesar $37,5 \%$ dan indikator 3 dengan rata-rata sebesar $56,8 \%$ belum memenuhi KKM yang ditentukan pada sekolah yaitu 75, sedangkan indikator 2 telah memenuhi KKM dengan rata-rata sebesar 100\%. Gambar grafik berikut menunjukkan skor siswa tentang sistem periodik unsur yang menggambarkan capaian penguasaan konsep tiap-tiap siswa. 


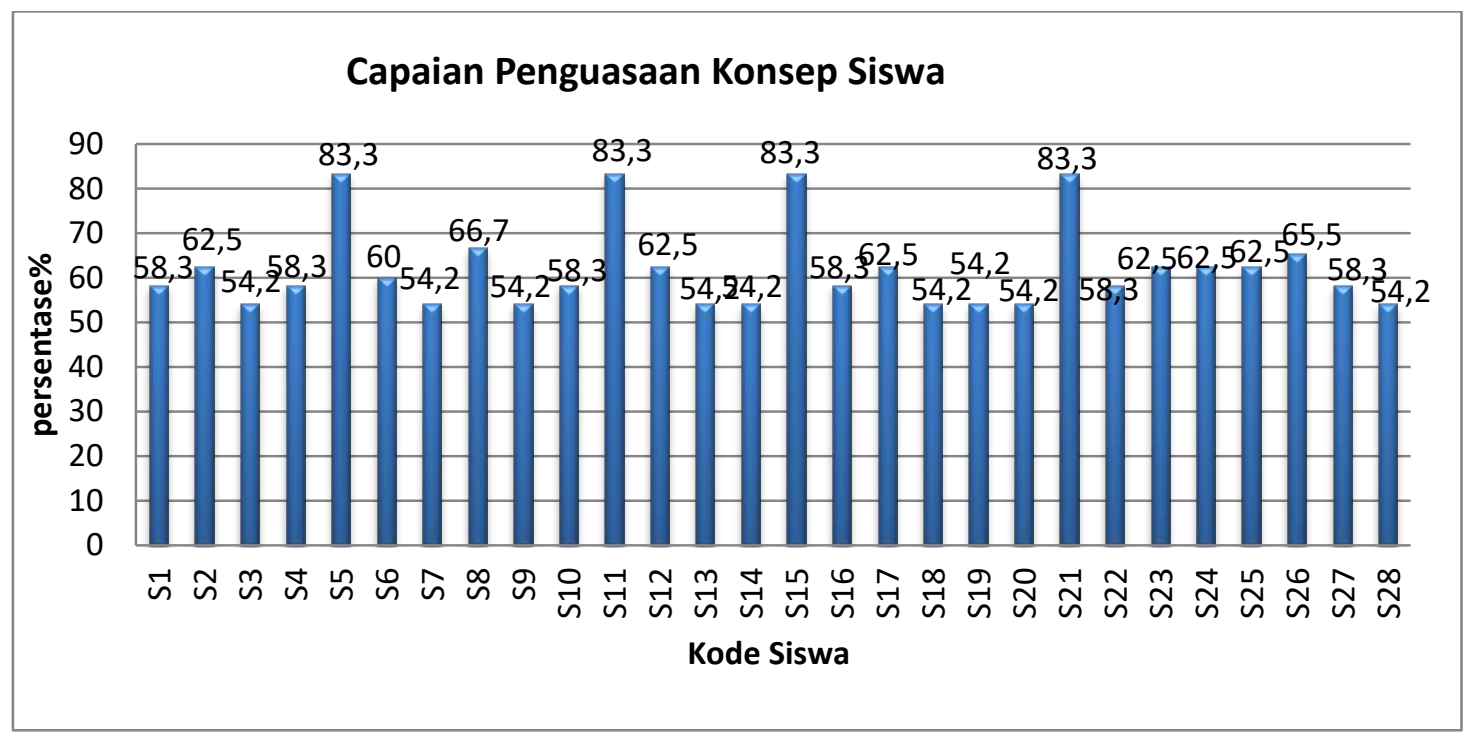

Gambar 2. Grafik Capaian Penguasaan Konsep Setiap Siswa

Penguasaan konsep siswa pada materi sistem periodik unsur seperti pada gambar di atas menunjukkan ada 5 siswa yang memperoleh nilai di atas KKM, dan 23 siswa memperoleh nilai di bawah KKM. Berdasarkan hasil persentase capaian penguasaan konsep siswa diperoleh 2 kategori penguasaan konsep yaitu kategori tinggi dan kategori sedang. Sebanyak 5 siswa berada pada kategori tinggi, dan sebanyak atau 23 siswa berada pada kategori sedang.

Rencana Pelaksanaan Pembelajaran (RPP) yang diamati dan dianalisis adalah RPP yang dibuat Guru berdasarkan kurikulum 2013. Untuk menganalisis RPP tersebut digunakan pedoman seperti Tabel berikut.

Tabel 4. Komponen Kelengkapan RPP yang Terpenuhi dan yang Tidak Terpenuhi

\begin{tabular}{|c|c|c|c|}
\hline No & Aspek yang Diamati & Ada & $\begin{array}{c}\text { Tidak } \\
\text { Ada }\end{array}$ \\
\hline \multirow{7}{*}{1} & Identitas Sekolah & $\sqrt{ }$ & \\
\hline & G. Satuan Pendidikan & $\sqrt{ }$ & \\
\hline & H. Kelas & $\sqrt{ }$ & \\
\hline & I. $\quad$ Semester & $\sqrt{ }$ & \\
\hline & J. Mata Pelajaran & $\sqrt{ }$ & \\
\hline & K. Materi Pokok & $\sqrt{ }$ & \\
\hline & L. Alokasi Waktu & $\sqrt{ }$ & \\
\hline \multirow{2}{*}{2} & Kompetensi Inti & $\sqrt{ }$ & \\
\hline & $\begin{array}{ll}\text { A } & \text { KI-1 }\end{array}$ & $\sqrt{ }$ & \\
\hline
\end{tabular}




\begin{tabular}{|c|c|c|c|}
\hline No & Aspek yang Diamati & Ada & $\begin{array}{c}\text { Tidak } \\
\text { Ada }\end{array}$ \\
\hline & B $\quad \mathrm{KI}-2$ & $\sqrt{ }$ & \\
\hline & C $\mathrm{KI}-3$ & $\sqrt{ }$ & \\
\hline & D $\quad \mathrm{KI}-4$ & $\sqrt{ }$ & \\
\hline 3 & Kompetensi Dasar & $\sqrt{ }$ & \\
\hline 4 & Indikator & $\sqrt{ }$ & \\
\hline 5 & Tujuan Pembelajaran & $\sqrt{ }$ & \\
\hline 6 & Materi Pembelajaran & $\sqrt{ }$ & \\
\hline 7 & Metode Pembelajaran & $\sqrt{ }$ & \\
\hline 8 & Media Pembelajaran & $\sqrt{ }$ & \\
\hline 9 & Sumber Belajar & $\sqrt{ }$ & \\
\hline \multirow{15}{*}{10} & Rencana Keoiatan Pemhelaiaraan & $\sqrt{ }$ & \\
\hline & Kegiatan pendahuluan/awal & $\sqrt{ }$ & \\
\hline & 4) Mengkondisikan peserta didik & $\sqrt{ }$ & \\
\hline & $\begin{array}{l}\text { A 5) Mengkaitkan materi sebelumnya } \\
\text { dengan materi yang akan dipelajari }\end{array}$ & $\sqrt{ }$ & \\
\hline & 6) Menyampaikan tujuan pembelajaran & $\sqrt{ }$ & \\
\hline & Kegiatan inti & $\sqrt{ }$ & \\
\hline & 6) Mengamati & $\sqrt{ }$ & \\
\hline & 7) Menanya & $\sqrt{ }$ & \\
\hline & B 8) Mengumpulkan data & $\sqrt{ }$ & \\
\hline & 9) Mengasosiasikan & $\sqrt{ }$ & \\
\hline & 10) Mengkomunikasikan & $\sqrt{ }$ & \\
\hline & Kegiatan Penutup & $\sqrt{ }$ & \\
\hline & 4) Meninjau kembali & $\sqrt{ }$ & \\
\hline & 5) Mengevaluasi & $\sqrt{ }$ & \\
\hline & 6) Tindak lanjut & $\sqrt{ }$ & \\
\hline \multirow{3}{*}{11} & Penilaian & $\sqrt{ }$ & \\
\hline & A Jenis/teknik penilaian & $\sqrt{ }$ & \\
\hline & B $\quad$ Bentuk instrumen dan instrument & $\sqrt{ }$ & \\
\hline
\end{tabular}

Berdasarkan data analisis komponen isi RPP guru, hasil analisis RPP tersebut secara umum isinya telah sesuai seperti pada aspek yang diamati. Adapun dalam penelitian ini, secara spesifik memperhatikan pada aspek keterkaitan antara KI (kompetensi inti), KD (kompetensi dasar), indikator pencapaian kompetensi, tujuan pembelajaran, dan materi pembelajaran. Berikut diuraikan keterkaitan antara komponen-komponen tersebut. 


\section{Deskripsi Penguasaan Konsep Siswa terhadap Materi Sistem Periodik Unsur}

\section{Menjelaskan Perkembangan Sistem Periodik Unsur (Indikator 1)}

Pembahasan mengenai penjelasan perkembangan sistem periodik unsur ini terbagi menjadi 2 konsep yang masing-masing mewakili tiap sub indikator. Sebagaimana dipaparkan dalam tabel 3 bahwa penguasaan konsep siswa pada sub indikator 1 berada pada kategori rendah dan sub indikator 2 berada pada kategori sedang.

\subsection{Mendeskripsikan dasar penyusun tabel sistem periodik unsur Triade Döbereiner, Oktaf Newlands, dan Mendeleev (sub indikator 1)}

Kemampuan siswa dalam mendeskripsikan dasar penyusun tabel sistem periodik unsur Triade Dobereiner, Oktaf Newland, dan Mendeleev sebagaimana dipaparkan pada tabel 3 sebesar $25 \%$ berada pada kategori rendah. Hal tersebut menunjukkan bahwa penguasaan konsep siswa masih rendah pada topik ini. Berikut disajikan tabel tentang perolehan skor siswa dalam mendeskripsikan dasar penyusun tabel sistem periodik unsur Triade Dobereriner, Oktaf Newland, dan Mendeleev.

Tabel 5. Distribusi Capaian Siswa pada Butir Soal 1

\begin{tabular}{ccccccc}
\hline Kategori & Jumlah Siswa & \multicolumn{5}{c}{ Jumlah Siswa dengan Skor } \\
\cline { 3 - 7 } Penguasaan & & $\mathbf{0}$ & $\mathbf{1}$ & $\mathbf{2}$ & $\mathbf{3}$ & $\mathbf{4}$ \\
\hline Tinggi & 5 & - & 5 & - & - & - \\
\hline Sedang & 23 & - & 23 & - & - & - \\
\hline Total & $\mathbf{2 8}$ & - & $\mathbf{2 8}$ & - & - & - \\
\hline Persentase (\%) & & - & $\mathbf{1 0 0 \%}$ & - & - & - \\
\hline
\end{tabular}

Tabel 5 menunjukkan bahwa sebesar $100 \%$ siswa memperoleh skor 1 artinya seluruh siswa hanya mampu menyebutkan dasar penyusun tabel sistem periodik unsur Triade Döbereiner, Oktaf Newlands, dan Mendeleev. Siswa 
tersebut telah menerima penjelasan guru, hanya saja siswa tidak memahami dengan baik tentang materi tersebut.

\subsection{Mendeskripsikan Dasar Penyusun Tabel Sistem Periodik Modern (Sub Indikator 2)}

Kemampuan siswa dalam mendeskripsikan dasar penyusun tabel sistem periodik unsur Modern sebagaimana dipaparkan pada tabel 3 sebesar 50\% berada pada kategori sedang. Hal tersebut menunjukkan bahwa penguasaan konsep siswa masih kurang pada topik ini. Berikut disajikan tabel tentang jumlah perolehan skor siswa dalam mendeskripsikan dasar penyusun tabel sistem periodik unsur Modern.

Tabel 6. Distribusi Capaian Siswa pada Butir Soal 2

\begin{tabular}{ccccc}
\hline Kategori & Jumlah Siswa & \multicolumn{3}{c}{ Jumlah Siswa dengan } \\
Penguasaan & & \multicolumn{3}{c}{ Skor } \\
\cline { 3 - 5 } & & $\mathbf{0}$ & $\mathbf{1}$ & $\mathbf{2}$ \\
\cline { 3 - 5 } Tinggi & 5 & - & 5 & - \\
\hline Sedang & 23 & - & 23 & - \\
\hline Total & $\mathbf{2 8}$ & - & $\mathbf{2 8}$ & - \\
\hline Persentase (\%) & & - & $\mathbf{1 0 0 \%}$ & - \\
\hline
\end{tabular}

Tabel 6 menunjukkan bahwa sebesar 100\% siswa memperoleh skor 1 artinya seluruh siswa hanya mampu menyebutkan dasar penyusun tabel sistem periodik unsur Modern. Siswa tersebut telah menerima penjelasan guru tentang sistem periodik unsur Modern, hanya saja para siswa tersebut tidak memahami dengan benar tentang materi tersebut.

\section{Menentukan Letak Suatu Unsur di dalam Tabel Periodik Berdasarkan Konfigurasi Elektron (Indikator 2)}

Pembahasan mengenai penentuan letak suatu unsur di dalam tabel periodik berdasarkan konfigurasi elektron ini terbagi kedalam 3 konsep yang masingmasing mewakili tiap sub indikator. Sebagaimana dipaparkan pada tabel 3 penguasaan konsep siswa menunjukkan bahwa pada sub indikator 1 berada pada 
kategori tinggi yaitu menuliskan konfigurasi elektron unsur golongan utama dan golongan transisi sebesar $100 \%$, sub indikator 2 yaitu menentukan golongan dan periode suatu unsur berdasarkan konfigurasi elektron sebesar 100\%, dan sub indikator 3 yaitu menentukan letak unsur pada tabel periodik sebesar $100 \%$. Berikut disajikan tabel perolehan skor siswa dalam menuliskan konfigurasi elektron unsur golongan, menentukan golongan dan periode unsur berdasarkan konfigurasi elektron, dan menentukan letak unsur dalam tabel periodik.

Tabel 7. Distribusi Capaian Siswa pada Butir Soal 3

\begin{tabular}{cccccc}
\hline Kategori & Jumlah & \multicolumn{4}{c}{ Jumlah Siswa dengan Skor } \\
\cline { 3 - 6 } Penguasaan & Siswa & $\mathbf{0}$ & $\mathbf{2}$ & $\mathbf{4}$ & $\mathbf{6}$ \\
\hline Tinggi & 5 & - & - & - & 5 \\
\hline Sedang & 23 & - & - & - & 23 \\
\hline Total & $\mathbf{2 8}$ & - & - & - & $\mathbf{2 8}$ \\
\hline Persentase (\%) & & - & - & - & $\mathbf{1 0 0 \%}$ \\
\hline
\end{tabular}

Tabel 7 menunjukkan bahwa sebesar 100\% siswa memperoleh skor 6 artinya seluruh siswa tersebut telah mampu menguasai konsep dalam menuliskan konfigurasi elektron, menentukan golongan dan periode, dan menentukan letak unsur pada tabel periodik. Siswa telah memiliki penguasaan konsep yang benar tentang konfigurasi elektron, periode dan golongan, serta letak suatu unsur pada tabel periodik.

\section{Menentukan sifat periodik suatu unsur (Indikator 3)}

Pembahasan mengenai penentuan sifat periodik suatu unsur ini terbagi ke dalam 6 konsep yang masing-masing mewakili tiap sub indikator. Sebagaimana dipaparkan dalam tabel 3 bahwa penguasaan konsep siswa pada sub indikator 1 hingga sub indikator 6 penguasaan konsep siswa berada pada kategori sedang.

\subsection{Mendeskripsikan Sifat Logam Suatu Unsur (Sub Indikator 1)}


Kemampuan siswa dalam mendeskripsikan sifat logam suatu unsur sebagaimana dipaparkan pada tabel 3 sebesar 53,6\% berada pada kategori sedang. Angka persentase menunjukkan bahwa sebagian besar siswa memiliki penguasan konsep yang baik pada topik ini. Berikut disajikan tabel tentang jumlah perolehan skor siswa dalam mendeskripsikan sifat logam suatu unsur.

\section{Tabel 8. Distribusi Capaian Siswa pada Butir Soal 4}

\begin{tabular}{ccccc}
\hline $\begin{array}{c}\text { Kategori } \\
\text { Penguasaan }\end{array}$ & Jumlah Siswa & \multicolumn{3}{c}{ Jumlah Siswa dengan Skor } \\
\cline { 3 - 5 } & & $\mathbf{0}$ & $\mathbf{1}$ & $\mathbf{2}$ \\
\hline Tinggi & 5 & - & - & 5 \\
\hline Sedang & 23 & 5 & 16 & 2 \\
\hline Total & $\mathbf{2 8}$ & $\mathbf{5}$ & $\mathbf{1 6}$ & $\mathbf{7}$ \\
\hline Persentase (\%) & & $\mathbf{1 8 \%}$ & $\mathbf{5 7 \%}$ & $\mathbf{2 5 \%}$ \\
\hline
\end{tabular}

Tabel 8 menunjukkan bahwa sebesar $18 \%$ siswa memperoleh skor 0 artinya siswa belum mampu menentukan sifat logam terbesar suatu unsur dan mendeskripsikan sifat logam terbesar suatu unsur atau siswa menjawab salah, sebesar 57\% siswa memperoleh skor 1 artinya sebagian besar siswa hanya mampu menentukan sifat logam terbesar suatu unsur tetapi masih belum tepat dalam menjelaskan alasan mengapa suatu unsur memiliki sifat logam kecil hingga terbesar, dan sebesar $25 \%$ siswa memperoleh skor 2 artinya hanya sedikit siswa yang mampu menentukan sifat logam terbesar suatu unsur dan mendeskripsikan sifat logam terbesar suatu unsur dengan benar.

\subsection{Mendeskripsikan Titik Didih dan Titik Leleh Suatu Unsur (Sub Indikator 2)}

Kemampuan siswa dalam mendeskripsikan titik didih dan titik leleh suatu unsur sebagaimana dipaparkan pada tabel 3 sebesar 58,9\% berada pada kategori sedang. Angka persentase tersebut menunjukkan bahwa sebagian besar siswa memiliki penguasaan konsep yang baik pada topik ini. Berikut disajikan tabel 
tentang jumlah perolehan skor siswa dalam mendeskripsikan titik didih dan titik leleh suatu unsur.

Tabel 9. Distribusi Capaian Siswa pada Butir Soal 5

\begin{tabular}{ccccc}
\hline $\begin{array}{c}\text { Kategori } \\
\text { Penguasaan }\end{array}$ & Jumlah Siswa & \multicolumn{3}{c}{ Jumlah Siswa dengan Skor } \\
\cline { 3 - 5 } & & $\mathbf{0}$ & $\mathbf{1}$ & $\mathbf{2}$ \\
\hline Tinggi & 5 & - & & 5 \\
\hline Sedang & 23 & 6 & 10 & 7 \\
\hline Total & $\mathbf{2 8}$ & $\mathbf{6}$ & $\mathbf{1 0}$ & $\mathbf{1 2}$ \\
\hline Persentase (\%) & & $\mathbf{2 1 , 4 \%}$ & $\mathbf{3 5 , 7 \%}$ & $\mathbf{4 2 , 9 \%}$ \\
\hline
\end{tabular}

Tabel 9 menunjukkan bahwa sebesar $21,4 \%$ siswa memperoleh skor 0 artinya siswa belum mampu menentukan titik didih dan titik leleh unsur paling tinggi dan mendeskripsikan titik didih dan titik leleh unsur atau menjawab salah, sebesar 35,7\% siswa memperoleh skor 1 artinya siswa hanya mampu menentukan titik didih dan titik leleh unsur paling tinggi tetapi belum tepat dalam menjelaskan alasan suatu unsur memiliki titik didih dan titik leleh tinggi, dan sebesar $42,9 \%$ siswa memperoleh skor 2 artinya siswa telah mampu menentukan titik didih dan titik leleh unsur paling tinggi dan mendeskripsikan titik didih dan titik leleh unsur dengan benar.

\subsection{Menentukan Jari-Jari Atom Terkecil Hingga Terbesar dari Suatu Unsur (Sub Indikator 3)}

Kemampuan siswa dalam menentukan jari-jari atom terkecil hingga terbesar suatu unsur sebagaimana dipaparkan pada tabel 3 sebesar $57,1 \%$ berada pada kategori sedang. Angka persentase menunjukkan bahwa sebagian besar siswa telah memiliki penguasaan konsep yang baik pada topik ini. Berikut disajikan tabel tentang jumlah perolehan skor siswa dalam menentukan jari-jari atom terkecil hingga terbesar suatu unsur. 
Tabel 10. Distribusi Capaian Siswa pada Butir Soal 6.a

\begin{tabular}{ccccc}
\hline $\begin{array}{c}\text { Kategori } \\
\text { Penguasaan }\end{array}$ & Jumlah Siswa & \multicolumn{3}{c}{ Jumlah Siswa dengan Skor } \\
\cline { 3 - 5 } & & $\mathbf{0}$ & $\mathbf{1}$ & $\mathbf{2}$ \\
\hline Tinggi & 5 & - & - & 5 \\
\hline Sedang & 23 & 2 & 19 & 2 \\
\hline Total & $\mathbf{2 8}$ & $\mathbf{2}$ & $\mathbf{1 9}$ & $\mathbf{7}$ \\
\hline Persentase (\%) & & $\mathbf{7 , 1 \%}$ & $\mathbf{6 7 , 9 \%}$ & $\mathbf{2 5 \%}$ \\
\hline
\end{tabular}

Tabel 10 menunjukkan bahwa sebesar 7,1\% siswa memperoleh skor 0 artinya siswa belum mampu menentukan jari-jari atom terkecil hingga terbesar dari suatu unsur dan menjelaskan kecenderungan jari-jari atom unsur atau siswa menjawab salah, sebesar $67,9 \%$ siswa memperoleh skor 1 artinya sebagian besar siswa hanya mampu menentukan jari-jari atom terkecil hingga terbesar dari suatu unsur tetapi belum tepat menjelaskan alasannya, dan sebesar $25 \%$ siswa memperoleh skor 2 artinya siswa telah mampu menentukan jari-jari atom terkecil hingga terbesar dari suatu unsur dan menjelaskan kecenderungan jari-jari atom unsur dengan benar.

\subsection{Menentukan Energi Ionisasi Terkecil Hingga Terbesar dari Suatu Unsur (Sub Indikator 4)}

Kemampuan siswa dalam menentukan energi ionisasi terkecil hingga terbesar suatu unsur sebagaimana dipaparkan pada tabel 3 sebesar 58,9\% berada pada kategori sedang. Angka persentase yang cukup menunjukkan bahwa sebagian besar siswa sudah memiliki penguasaan konsep yang baik pada topik ini. Berikut disajikan tabel tentang jumlah perolehan skor siswa dalam menentukan energi ionisasi terkecil hingga terbesar suatu unsur.

Tabel 11. Distribusi Capaian Siswa pada Butir Soal 6.b

\begin{tabular}{ccccc}
\hline Kategori & Jumlah Siswa & \multicolumn{3}{c}{ Jumlah Siswa dengan Skor } \\
\cline { 3 - 5 } Penguasaan & & $\mathbf{0}$ & $\mathbf{1}$ & $\mathbf{2}$ \\
\hline Tinggi & 5 & - & - & 5 \\
\hline Sedang & 23 & - & 22 & 1 \\
\hline
\end{tabular}




\begin{tabular}{ccccc}
\hline Total & 28 & - & 22 & 6 \\
\hline Persentase $(\%)$ & & - & $\mathbf{7 8 , 6 \%}$ & $\mathbf{2 1 , 4 \%}$ \\
\hline
\end{tabular}

Tabel 11 menunjukkan bahwa tidak ada siswa memperoleh skor 0, sebesar $78,6 \%$ siswa memperoleh skor 1 artinya sebagian besar siswa hanya mampu menentukan energi ionisasi terkecil hingga terbesar dari suatu unsur tetapi belum tepat dalam menjelaskan alasannya, dan sebesar 21,4\% siswa memperoleh skor 2 artinya siswa telah mampu menentukan energi ionisasi terkecil hingga terbesar dari suatu unsur dan menjelaskan kecenderungan energi ionisasi unsur dengan benar.

\subsection{Menentukkan Afinitas Elektron Terkecil Hingga Terbesar dari Suatu Unsur (Sub Indikator 5)}

Kemampuan siswa dalam menentukan afinitas elektron terkecil hingga terbesar suatu unsur sebagaimana dipaparkan pada tabel 3 sebesar 57,1\% berada pada kategori sedang. Angka persentase yang cukup menunjukkan bahwa sebagian besar siswa sudah memiliki penguasaan konsep yang baik pada topik ini. Berikut disajikan tabel tentang jumlah perolehan skor dalam menentukan afinitas elektron terkecil hingga terbesar suatu unsur.

Tabel 12. Distribusi Capaian Siswa pada Butir Soal 6.c

\begin{tabular}{ccccc}
\hline $\begin{array}{c}\text { Kategori } \\
\text { Penguasaan }\end{array}$ & Jumlah Siswa & \multicolumn{3}{c}{ Jumlah Siswa dengan Skor } \\
\cline { 3 - 5 } & & $\mathbf{0}$ & $\mathbf{1}$ & $\mathbf{2}$ \\
\hline Tinggi & 5 & - & - & 5 \\
\hline Sedang & 23 & 1 & 21 & 1 \\
\hline Total & $\mathbf{2 8}$ & $\mathbf{1}$ & $\mathbf{2 1}$ & $\mathbf{6}$ \\
\hline Persentase $(\%)$ & & $\mathbf{3 , 6 \%}$ & $\mathbf{7 5 \%}$ & $\mathbf{2 1 , 4 \%}$ \\
\hline
\end{tabular}

Tabel 12 menunjukkan bahwa sebesar 3,6\% siswa memperoleh skor 0 artinya siswa tersebut belum mampu menentukan afinitas elektron terkecil hingga terbesar dari suatu unsur dan menjelaskan kecenderungan energi ionisasi unsur atau menjawab salah, sebesar $75 \%$ siswa memperoleh skor 1 artinya sebagian 
besar siswa hanya mampu menentukan afinitas elektron terkecil hingga terbesar dari suatu unsur tetapi belum tepat dalam menjelaskan alasannya, dan sebesar 21,4\% siswa memperoleh skor 2 artinya siswa telah mampu menentukan afinitas elektron terkecil hingga terbesar dari suatu unsur dan menjelaskan kecenderungan afinitas elektron unsur dengan benar.

\subsection{Menentukkan Keelektronegatifan Terkecil Hingga Terbesar dari Suatu Unsur (Sub Indikator 6)}

Kemampuan siswa dalam menentukan keelektronegatifan terkecil hingga terbesar suatu unsur sebagaimana dipaparkan pada tabel 3 sebesar 55,4\% berada pada kategori sedang. Angka persentase menunjukkan bahwa sebagian besar siswa sudah memiliki penguasaan konsep yang baik pada topik ini. Berikut disajikan tabel tentang jumlah perolehan skor siswa dalam menentukan keelektronegatifan terkecil hingga terbesar suatu unsur.

Tabel 13. Distribusi Capaian Siswa pada Butir Soal 6.d

\begin{tabular}{ccccc}
\hline $\begin{array}{c}\text { Kategori } \\
\text { Penguasaan }\end{array}$ & Jumlah Siswa & \multicolumn{3}{c}{ Jumlah Siswa dengan Skor } \\
\cline { 3 - 5 } & & $\mathbf{0}$ & $\mathbf{1}$ & $\mathbf{2}$ \\
\hline Tinggi & 5 & - & - & 5 \\
\hline Sedang & 23 & 2 & 20 & 1 \\
\hline Total & $\mathbf{2 8}$ & $\mathbf{2}$ & $\mathbf{2 0}$ & $\mathbf{6}$ \\
\hline Persentase (\%) & & $\mathbf{7 \%}$ & $\mathbf{7 1 \%}$ & $\mathbf{2 2 \%}$ \\
\hline
\end{tabular}

Tabel 13 menunjukkan bahwa sebesar 7\% siswa memperoleh skor 0 artinya siswa tersebut belum mampu menentukan keelektronegatifan terkecil hingga terbesar dari suatu unsur dan menjelaskan kecenderungan keelektronegatifan unsur atau menjawab salah, sebesar $71 \%$ siswa memperoleh skor 1 artinya sebagian besar siswa hanya mampu menentukan keelektronegatifan terkecil hingga terbesar dari suatu unsur tetapi belum tepat dalam menjelaskan alasannya, dan sebesar $22 \%$ siswa memperoleh skor 2 artinya siswa telah mampu 
menentukan keelektronegatifan terkecil hingga terbesar dari suatu unsur dan menjelaskan kecenderungan keelektronegatifan unsur dengan benar.

\section{Kesimpulan}

Berdasarkan hasil penelitian dan analisis data yang telah dilakukan dapat disimpulkan sebagai berikut:

1. Rata-rata penguasaan konsep siswa pada topik sistem periodik unsur sebesar $61,7 \%$ berada pada kategori sedang. Penguasaan konsep siswa terbagi kedalam 2 kategori yaitu tinggi dan sedang. Sebanyak 5 siswa berada pada kategori tinggi, dan sebanyak 23 siswa berada pada kategori sedang.

2. Penguasaan konsep siswa dalam menjelaskan perkembangan sistem periodik unsur yaitu sebesar $37,5 \%$ berada pada kategori rendah.

3. Penguasaan konsep siswa dalam menentukan letak suatu unsur di dalam tabel periodik berdasarkan konfigurasi elektron yaitu sebesar $100 \%$ berada pada kategori tinggi.

4. Penguasaan konsep siswa dalam menentukan sifat periodik suatu unsur yaitu sebesar $56,8 \%$ berada pada kategori sedang.

\section{Saran}

Hasil penelitian diperoleh bahwa rata-rata penguasaan konsep siswa pada materi sistem periodik unsur dibawah nilai KKM. Dalam hal ini guru harus benarbenar menyediakan kondisi belajar yang menyenangkan agar dapat menumbuhkan minat siswa dalam belajar konsep kimia lainnya. Sebelum dilakukannya tes, guru bisa memberikan pengayaan soal dan membahas soal yang sudah pernah diberikan sebelumnya supaya konsep-konsepnnya lebih diperkuat lagi. Selain itu, guru sebaiknya memilih model pembelajaran yang tepat. Sehingga kesalahankesalahan yang siswa lakukan pada materi sistem periodik unsur tidak berulangulang.

\section{Daftar Pustaka}

Arifin, Mulyati. (1995). Program Pengembangan Pembelajaran Bidang Studi Kimia. Surabaya: Airlangga University Press.

Arikunto, S. (2007). Prosedur Penelitian Suatu Pendekatan Praktek Edisi Revisi VI. Jakarta: Rineka Apta. 
Jumantias, Triana. (2018). Analisis Pemahaman Konsep Bentuk Molekul pada Siswa Kelas XI MIA 3 SMA Negeri 3 Pangkalan Bun Tahun Ajaran 2017/2018. Skripsi. Tidak Diterbitkan: Universitas Palangka Raya.

Mawarni, Ika. (2017). Deskripsi Kesalahan Siswa SMAN 3 Pontianak dalam Menyelesaikan Soal Struktur Atom dan Sistem Periodik Unsur. Dikutip pada 16 Mei 2018.

Moeloeng, Lexy J. (2004). Metodologi Penelitian Kualitatif. Bandung: PT. Remaja Rosdakarya.

Rahmaningsih, dkk. (2012). Menggali Pemahaman Konsep Siswa Madrasah Aliyah X Tentang Keperiodikan Unsur Menggunakan Instrumen Diagnostik Twotier.

Sanjaya, Dicky. (2017). Pemahaman Konsep Sifat Keperiodikan Unsur Hasil Pembelajaran Berbantuan LKS-Induktif dengan Menggunakan Model Kooperatif Tipe STAD (Student Team Achievment Division) Pada Siswa Kelas X-3 MIA SMA Negeri 4 Palangka Raya Tahun Ajaran 2016/2017. Skripsi. Tidak Diterbitkan: Universitas Palangka Raya. 